\section{Detection of a length polymorphism for human GIP gene by polymerase chain reaction}

T.L.Johnson, B.E.Reus, A.L.Culpepper, S.L.Naylor and R.J.Leach*

Department of Cellular and Structural Biology, The

University of Texas Health Science Center at San Antonio, San Antonio, TX 78284, USA

Source and Description: Takeda et al. (1) reported a cDNA sequence for human GIP. We selected primers for polymerase chain reaction (PCR) from the $3^{\prime}$ end of the coding sequence and extending into the untranslated region of the human GIP gene. The forward primer is 5'-CACAATGGGCTCGACTTAGCATAA-3', the reverse primer is 5'-CTTGCTGGATCAGACAAACCTCTG-3'. The expected amplification product based on cDNA sequence was $165 \mathrm{bp}$, however, a 1800 bp product was observed, implying these primers span an intron.

Protocol: Each amplification reaction consisted of $100 \mathrm{ng}$ genomic DNA, $10 \mathrm{ng}$ of each primer, $1 \times$ reaction buffer as supplied by manufacturer (Promega), $200 \mu \mathrm{M}$ of each nucleotide triphosphate, and 1.2 units Taq DNA polymerase (Promega) in a reaction volume of $20 \mu \mathrm{l}$. Each reaction mixture was denatured at $95^{\circ} \mathrm{C}$ for 5 minutes, followed by 30 cycles of PCR with primer annealing at $60^{\circ} \mathrm{C}$ for 2 minutes, elongation at $72^{\circ} \mathrm{C}$ for 3 minutes and denaturation at $94^{\circ} \mathrm{C}$ for 1 minute. The final cycle consisted of a 10 minute $72^{\circ} \mathrm{C}$ elongation followed by rapid cooling to $4^{\circ} \mathrm{C}$. PCR products were electrophoresed on $0.8 \%$ agarose gels.

Polymorphism: Allele A1 produces a PCR product of approximately $1950 \mathrm{bp}$, allele A2 produces a product of approximately $1800 \mathrm{bp}$, and allele $\mathrm{A} 3$ produces a product of approximately $1650 \mathrm{bp}$.

Frequency: In 24 unrelated individuals the frequency of allele 1 was 0.44 , the frequency of allele 2 was 0.50 , and the frequency of allele 3 was 0.06 .

Chromosomal Localization: 17q21.3-q22.

Mendelian Inheritance: Co-dominant inheritance was observed in one three generation family with 8 members.

Acknowledgement: We thank Dr. Stephen Ryan for providing the BFNC family DNA.

Reference: 1) Takeda,J., Seino,Y., Tanaka,K.-I., Fukumoto,H., Kayano,T., Takahashi,H., Mitani,T., Kurono,M., Suzuki,T., Tobe,T. and Imura,H. (1987) Proc. Natl. Acad. Sci. USA 84, 7005-7008.

\section{Drall and $\mathrm{Xmnl}$ polymorphisms at the human parathyroid hormone locus}

J.J.Shields, J.E.Mullersman and B.K.Saha*

Department of Pathology, Washington University School

of Medicine, St Louis, MO 63110, USA

Source/Description: The plasmid p20.36 which contains an EcoRI fragment encompassing the human parathyroid hormone gene was utilized as a probe (1).

Polymorphisms: Drall identifies a two allele polymorphism (allele $\mathrm{C1}$ : $15.0 \mathrm{~kb}$, allele C2: $16.5 \mathrm{~kb}$ ). XmnI (or Asp700I) identifies a two allele polymorphism (allele D1: $4.5 \mathrm{~kb}$, allele D2: $6.0 \mathrm{~kb}$ ).

Frequency: Estimated from 120 chromosomes of unrelated individuals for DraII:

C1: 0.86

C2: 0.14

Estimated from 88 chromosomes of unrelated individuals for XmnI:

D1: 0.60

D2: 0.40

Also Polymorphic For: PstI and TaqI (1).

Chromosomal Localization: 11p15 $(2,3)$.

Mendelian Inheritance: Analysis of a large CEPH family (8 children) yielded results indicative of co-dominant inheritance.

Probe Availability: American Type Culture Collection.

References: 1) Schmidtke,J. et al. (1984) Hum. Genet. 67, 428-431. 2) Mayer,H. et al. (1983) Hum. Genet. 64, 283-285. 3) Naylor,S.L. et al. (1983) Somatic Cell Mol. Genet. 9, 609-616. 